\title{
Medical Malpractice in Israel and the Financial and Non-financial Damage to the Victim
}

\author{
Natali Levin \\ Department of Philosophy, Faculty of Social Sciences, Adam Mickiewicz University in Poznań (AMU), Poland
}

Copyright $(2017$ by authors, all rights reserved. Authors agree that this article remains permanently open access under the terms of the Creative Commons Attribution License 4.0 International License

\begin{abstract}
The goal of tort law and medical malpractice lawsuits is to restore the situation to its previous state. Namely, the compensation awarded to the victim aspires to return him to the situation before the damage was caused. However, this is not simple, since it is very difficult to measure mental damage or suffering experienced by the victim and to quantify it as financial payment. In tort lawsuits, including medical malpractice, there is a precise definition of the financial damage. The definition includes loss or any expense that can be quantified in money and can be detailed. In essence, it can be said that the Tort Ordinance does not provide a response as to how to calculate the damage, or a formula which defines the compensation and calculation of damage. The Courts in Israel differentiated between two types of pecuniary damage: general damage and special damage. The law in Israel does not determine a way to calculate compensation for pain and suffering of the victim, and the judge must form his impression regarding the medical opinion and calculate the scope of the suffering. The ruling determined criteria that influence the sum of the compensation. The age of the victim at the time of the accident affects the sum of the compensation awarded for pain and suffering. The Court, for the most part, examines the effect of the type of damage and its scope and its effect on the victim's quality of life.
\end{abstract}

Keywords Torts, Medical Malpractice in Israel, Pecuniary Damage and Non Pecuniary Damage

\section{Laws and Regulations Regarding Medical Malpractice Lawsuits in Israel}

There is no specific law discussing medical malpractice lawsuits in Israel. There existing laws refer to the tort of negligence, medical assault, breach of statutory duty, and breach of the provisions of the Patient's Rights Law.

The tort of negligence, appearing in Articles 35 and 36 of the Tort Ordinance [1], states that:

35. Where a person does an act which under the same circumstances a reasonable careful person would not do, or fails to do an act which under the circumstances such a person would do, or fails to use such skill or take such care when exercising any occupation as a reasonable careful person qualified to exercise such occupation would use or take under the same circumstances, then such act or failure constitutes carelessness and a person's carelessness as aforesaid in relation to another person to whom he owes a duty under the circumstances not to act that way, constitutes negligence. Any person who causes damage to any person by his negligence commits a civil wrong.

36. For the purpose of Article 35, every person owes a duty to all persons, and the owner of any property to which, a reasonable person ought, under the same circumstances, to have contemplated as likely in the usual course of things to be affected by an act, or failure to do an act envisaged by that Article.

The lawsuit on negligence as determined in the Torts Ordinance is a framework tort permitting the legislature to determine criteria of damaging and damaged factors, when in the relations between them there is the duty of care. In the analysis of the grounds of negligence, there are the elements of the duty of care, carelessness (breach of the duty of care), and damage.

In medical malpractice lawsuits, the test that should be examined is the test of the 'reasonable physician'. Are the decisions and actions of the physician reasonable and accepted in medicine? The physician must consider his actions according to the most recent developments in medicine and according to the treatments accepted globally. A reasonable physician needs to exert his judgment and be updated in contemporary medicine.

The examination of negligence examines the time of the case and not the time of the lawsuit. Namely, if medicine has advanced and found solutions over the years to the medical case discussed, then the examination of the physician's negligence is examined at the time of the event. 
When examining case, the relevant test of negligence is the test of expectations. A legal causal relationship with medical malpractice exists when the manner in which the damage was caused is an expected result of carelessness.

It is possible to establish a claim for medical treatment without informed consent on the tort of assault found in the Torts Ordinance, Article 23:

23. Assault consists of intentionally applying force of any kind, whether by way of striking, touching, moving or otherwise, to the person of another, either directly or indirectly, without his consent, or with his consent if the consent is obtained by fraud, or attempting or threatening by any act or gesture to apply such force to the person or another if the person making the attempt or threat causes the other to believe upon reasonable grounds that he has the present intention and ability to effect his purpose.

(b) "Applying force" - for the purposes of this section, includes applying heat, light, electrical force, gas, odor or any other substance or matter whatever if applied in such a degree as to cause damage.

The cause of the assault is established on the foundations of every contact of the damaged party without his consent, therefore medical assault meets the requirements of the law, despite the medical assault being that of a physician with good intentions.

Article 24 of the Torts Ordinance lists the defense of the tort of assault. Section8 of Article 24 states:

(8) [If the defendant] acted in good faith for what he had reason to believe to be for the benefit of the plaintiff, but was unable before doing such an act, to obtain the consent of the plaintiff thereto, as the circumstances were such that it was impossible for the plaintiff to signify his consent or for some person in lawful charge of the plaintiff to consent on behalf of the plaintiff, and the defendant had reason to believe that it was for the benefit of the plaintiff that he should not delay in doing such act.

The doctrine of informed consent obtained from the patient for treatment is based on the fundamental concepts of autonomy, freedom, and privacy. The patient has the right to be informed about the process and condition of his illness and to participate in the decisions regarding the treatment he will undergo [2].

In essence, these are further grounds supporting the tort of negligence - failure to obtain informed consent in accordance with the requirement of the law. The duty is to provide the patient with information, before the medical treatment, as noted in Article 13 of the Patient's Rights Law. It is possible to file a lawsuit for damage to the patient's autonomy if the risks of the medical treatment are not explained to the patient.

The Patient's Rights Law, 1996, expressly determined the duty to obtain the patient's informed consent before providing medical treatment. The intention is not only for the patient to consent to the treatment but also for the patient to express his consent after he has been informed about the treatment and about the risks involved in this type of treatment.

Informed consent is when the patient expresses his full consent and knows about all treatment options, including alternative treatment methods. The scope of disclosure to the patient is that there is the obligation to provide an explanation according to the needs of the 'reasonable patient'. It is necessary for this explanation to be in the patient's language, accomplished professionally and according to the patient's equivalent capacity.

Article 13 of the Patient's Rights Law [3] states:

(a) Medical treatment will not be given to a patient without the patient's informed consent, in accordance with the provisions of this chapter.

(b) In order to receive the informed consent of a patient, the treatment provider will provide the patient with all medical information reasonably required by him, to enable him to decide whether to agree to the proposed medical treatment;

\section{Types of Damage: Pecuniary and Non-pecuniary Damage}

The goal of tort law and medical malpractice lawsuits is to restore the situation to its previous state(restitutio in integrum). Namely, the compensation awarded to the damaged party aspires to return him to the situation before the damage was caused.

However, the situation is not simple. It is very difficult to estimate the mental damage or great suffering that the damaged party experienced and to quantify it into a financial payment.

The Court must place at the disposal of the damaged party a sum of money that can enable him to make acquisitions that will take the place of what he has lost. Thus, if the damage is of pain and suffering and awareness of the loss of the pleasures of life, then compensation is awarded that will enable the damaged party to acquire other pleasures that will balance out with the damage inflicted [4].

In a medical malpractice lawsuit there is a precise definition of financial damage, as defined in Article 2 of the Torts Ordinance [5], as follows: "Damage - loss of life, or loss of, or damage to, any property, comfort, bodily welfare, reputation or other similar loss or damage". This definition is broad, referring both to the matter of the types of damage mentioned in the first part and to the matter of those mentioned in the second part. It includes all types of damage, including physical and non-physical, pecuniary and non-pecuniary.

At the basis of the definition there is the concrete reality. It encompasses both physical damage and pecuniary damage, both damage to the physical feelings and comfort, which will have physical expression and damage to the physical feelings 
and comfort, which does not have physical expression.

It is possible to say that the Torts Ordinance does not give us a response as to the way in which the damage is calculated or a formula that defines the compensation and its calculation. First, there is lack of clarity as well as lack of agreement, regarding the intellectual basis of the ruling of compensation when the damage is not property. When we lack a general intellectual infrastructure, naturally it is difficult to provide a solution to specific questions. Second, there is difficulty in the quantification of the damage and the determination of the compensation. How is pain and suffering valuated? How is the loss of the pleasures of life appraised? Is there a market price for the pleasures of life?

The theme is that "no money in the world can compensate for the pains of the body and mind, for the reduction of the chances of establishing a family, or for the loss of pleasures of normal life" [6] and that it is not possible to compensate with money a person who has lost a limb or who remains with a defect for the rest of his life. Even if we fill the damaged party's home with silver and gold, we cannot correct the damage caused [7]. How is it possible to precisely or even approximately estimate in money or a monetary equivalent the pain and suffering or the sorrow and shame of a person whose hand or leg has been amputated or of a person who walks on his legs and worries in his heart that his days are numbered?

However, the accepted approach is that, despite all the difficulties, it is necessary to valuate and determine the compensation. The reason is that it would be paradoxical if the law were to refuse to grant any compensation since no compensation is equivalent to the damage [8].

In pecuniary damage there are heads of torts that are included with regard to earnings: loss of salary as in the past, caused in actuality to the victim until the day of the Court Ruling, damage to the ability to earn in the future, loss of pension, damages included for healthcare provided by a third party in the past and in the future, mobility assistance in the past and in the future, and other medical expenditures (travel, etc.) in the past and in the future.

Contrary to the pecuniary damage that is not defined in the Torts Ordinance, the Court rulings have developed the concept that the intention of damage in the general term includes pain and suffering and shortening of the life span. In the case of the death of the victim, there are burial expenses and the lawsuit brought by the dependents who suffered from the absence of the victim's support.

The Courts in Israel differentiated between two types of pecuniary damage - general damage and special damage. All damage that occurred until the day that the Court Ruling was given or the compromise was reached is included as special damage, and every damage from the day of the Court Ruling or compromise and onwards is called general damage. An exception to these types of damage is non-pecuniary damage, which is not defined for periods but is calculated from the beginning of the incident until the end of the victim's life.

The law in Israel does not determine a way of calculation for compensation for pain and suffering and the judge must take into consideration the medical opinion and calculate the scope of the suffering. The Court Ruling determined criteria that influence the sum of the compensation.

The age of the damaged party at the time of the accident affects the sum of the compensation awarded for pain and suffering. As the age is lower, it can be expected that the person will suffer for a longer period of time, thus the mental effect of the damage is longer on the continuation of functioning throughout [9].

Sometimes the later age of the damaged party can influence the compensation for pain and suffering. Damage to an older person can cause a significant change to his quality of life, and therefore the Court addresses the compensation for his suffering in the head of torts of pain and suffering and gives a high compensation. The Court for the most part examines the influence of the type of damage, the scope of the damage, and the influence on the damaged party's quality of life. There are additional considerations for head of tort, including ugliness and scarring caused as a result of the damage, loss of chance to marry, loss of fertility, mental-emotional suffering as a result of the physical damage.

In the Gordon Ruling [10], the Court ruled in a case where a person sold his car but parking tickets continued to be sent to him under his name and his refusal to pay them led to his arrest. Judge Barak determined that the wrongs in the Torts Ordinance overlap one another. A protected interest can receive the protection of a number of particular torts and by a framework tort, such as negligence. A public organization, like any other party causing damage, must adopt reasonable means of caution to avoid the damage. He sometimes uses a good 'damage distributor', which may justify the placement of responsibility on him. In this way, it is ensured that means of safety in the future are adopted to prevent the recurrence of the incident of negligence.

It is also possible to compensate for non-property damage, if a reasonable person has the duty (conceptual and concrete) to expect the occurrence. Because of carelessness there is the right to compensation also for damage without physical damage but for mental-emotional suffering. Following this incident it was determined that it is possible to receive compensation for mental-emotional damage for damage to others [11].

\section{Positions of the Judge on Compensation for Non-pecuniary Damage}

The Supreme Court Judge Aharon Barak dictated three approaches on non-pecuniary damage, for pain and suffering, and for the shortening of the life span.

\subsection{The Functional Approach}

According to this approach, the sum is calculated with 
reference to substitutes. For a person whose life has been shortened, the sum of the compensation will enable the damaged party to acquire enjoyment from the remaining years of life. The compensation will include 'pleasures of life'. In the case of loss of consciousness, compensation will not be given for non-property damage, since in this approach it is not possible to give alternative pleasures. According to this approach, the damaged party is entitled to compensation for 'the pleasures of life' where it is possible to purchase with the compensation money alternative pleasures. Hence, there is no room to recognize the loss of pleasures of life as a separate head of tort, in its own right, but it should be seen as a part of the wider range of pain and suffering. Hence, the damaged party that permanently lost consciousness and does not return to it by the time he dies and does not feel what is around him will not receive compensation for the non-property damage, since there is no possibility of giving him alternative pleasures [12].

\subsection{The Personal Approach}

According to this approach, it is necessary to focus on the damaged party and on his happiness. In this approach, the compensation for the non-property damage intends to compensate for the loss of happiness and the enjoyment for the damaged party following the tort.

The meaning is that the pianist who lost his hand will receive greater compensation than that of a singer who does not use his hand. The compensation for pain and suffering and loss of pleasures in life is based, therefore, on the subjective damage of the enjoyment of the life. Even compensation for loss of life span is based on loss of "the chance for a life with an advantage for happiness".

If the nature of the damage changes and he is not aware of it, and from a subjective perspective his life is improved, then the damaged party cannot obtain compensation for this damage.

\subsection{The Property Approach}

According to this approach, the life of the damaged party, the integrity of his body in autonomous and psychological terms, his ability to enjoy his life, pain and suffering - all these are personal 'assets' of value. To negate an asset of this type is to negate property right. Every asset has an objective value, for which compensation can be awarded in the case of damage. The damage to this 'asset' even grants compensation in the non-property dimension. Hence, when the 'asset' is damaged the damaged party is entitled to compensation.

All three approaches, functional, personal, and property, have advantages and disadvantages. Some argue against the personal approach that is based on the damaged party's happiness since it is not possible to know what his happiness is and it cannot be evaluated. In essence, the Court can evaluate the person's happiness and what was taken from him by the damage, but the judge knows to evaluate the scope of one person's loss on the basis of the loss of happiness, when moreover this is the future and not the past [13].

Regarding the property approach, the following question has been raised. How can we evaluate the value of an 'asset' and how can we evaluate the damage to it?

Judge Barak, according to his approach, supports granting compensation for all intangible damage, even if the damaged party does not feel his suffering. At the head of the tort, where it is necessary to recognize the 'loss of the enjoyments of life', it is necessary to determine according to the personal approach that suits the damage of the damaged party and it is necessary to prefer the functional approach if this is possible [14].

The decision between the models is a difficult decision but primarily it is a question based on the philosophy of life itself. Over the years the Courts have attempted to formulate standards regarding compensation for non-pecuniary damage, and therefore it was determined that the test is not that of a border but an essence. Compensation needs to reflect the damage to the individual damaged party and the implications on him.

\section{Positions of the Ministry of Finance and Ministry of Health on Compensation for Pain and Suffering}

The position of the Ministry of Finance and the Ministry of Health is that it is justified to limit the compensation for pain and suffering. In their opinion, medical malpractice has unique characteristics that can indicate the trend of increase in the number of claims and in the scope of the compensation ruled and that justify the unique arrangement in legislation. In the end, the rise in the costs of medical malpractice for the public and private medical activity reduces the scope of the resources that the health system can allocate to the other medical services. Hence, there is a public interest to reduce the scope of the compensation so as to reduce the costs of the professional insurance. Thus, the scope of the resources that will be possible to be utilized to supply medical services for the benefit of the public at large will increase.

The Ministry of Health and the Ministry of Finance emphasize the need for certainty, so that the insurers can more precisely evaluate their risk and the sums that they may need to pay. In their opinion, the certainty will be achieved in that precise sums and the way to calculate them will be determined. (In other words, there will be a formula according to which the compensation will be calculated in the framework of the ceiling that will be set.) The Ministry of Health and the Ministry of Finance further hold that even if it is said that the rise in the costs of the lawsuits for bodily damage exists, if at all, in additional areas and is not unique to the field of medical malpractice, in light of the uniqueness of the structure of the public medical system in Israel and how it is funded, the rise in the field of medical malpractice has significant implications on the public purse, which necessitate and justify unique treatment [15]. 


\section{Summary}

Nonpecuniary harm belongs to the more human field of the work of law, and matters of the harmed party's pain and suffering as a person who represents a world in his own right make it difficult to be precise in the normative sense. Since this harm is a part of life, the need arises to arrange a framework for the identification of the tort relations between the litigants. The head of tort of the pain and suffering type for the person's body is not foreign to the law, and just as the harmed party is a person, the judge hearing the case is too.

The legal tools used to evaluate the damages are more correct for the pecuniary heads of tort, however the parallel use of these tools for the nonpecuniary harm leads to an unfair trial, lacking a uniformity of result and the involvement of subjective values in the law. Indeed, it is difficult for a person with the status of a judge to produce a result that worsens the situation of the harmed party in front of him, but this should not be seen as a weakness but as a strength. The power of judicial independence bears also the need for objectivity while setting a warning sign against identification with the harmed party.

In contemporary reality, the lack of defined standards that indicate uniformity in the ruling of damages for the head of tort of physical pain and suffering explains to a large extent the reason why these harms have been and will continue to be a focus for discussion.

\section{REFERENCES}

[1] Torts Ordinance [New Version], 1968.
[2] J. A. Martinez, J. M. Lyons, \& J. P. O’Leary (2009). Medical Malpractice Matters: Informed Consent, Journal of Surgical Education, May-June, 66 (3), 174-175.

[3] Patient's Rights Law, 1996.

[4] A. Barak, Evaluation of Compensations in Bodily Injuries", Studies in Law, 9 (9) 263, 1983.

[5] Article 2, Torts Ordinance, 1968.

[6] Civil Appeal 541/63 Reches and Others v. Herzenberg, Court Ruling 18 (2) 120, 126, Judge Branzon.

[7] 140/50 Yoni v. Fink, Court 11 35, 37, Judge Etzioni.

[8] A. Barak, Evaluation of Compensations in Bodily Injuries", Studies in Law, 9, 1983, 263.

[9] The Ministry of Health of Israel (2005).Position Paper for the Examination of Ways to Reduce the Public Expenditure for Medical Malpractice Suits. Jerusalem, November.

[10] Civil Appeal 243/83 Jerusalem Municipality v. Gordon, Court Ruling 39 (1) 113.

[11] E. Azar, \& A. Nirenberg, (2000). Medical Malpractice, Second Edition. (Hebrew).

[12] Teubner v. Humble (1962) 108 C. L. R. 491, 506; Skeleton v. Collins, supranote 136; A.Ogus, "Damages for Lost Amenities: For a foot, a feeling or a function" 35 M. L .R (1972).

[13] Civil Appeal 15/66 Shinar v. Hassan, Court Ruling 20(2), 455, 460 (1966).

[14] D. Katzir (2003).Compensations for Bodily Injury, Fifth Edition.(Hebrew).

[15] The Ministry of Health of Israel (2005).Position Paper for the Examination of Ways to Reduce the Public Expenditure for Medical Malpractice Suits. Jerusalem, November. 